\title{
G somentem \\ Establishment and Application of a Taqman Reverse Transcriptase Quantitative Real Time Pcr Assay for Feline Calicivirus
}

jingjie zhao

Chinese Academy of Agricultural Sciences https://orcid.org/0000-0003-3012-9588

\section{Lin Liang}

CAAS IAS: Chinese Academy of Agricultural Sciences Institute of Animal Science

\section{Guangzhi Zhang}

CAAS IAS: Chinese Academy of Agricultural Sciences Institute of Animal Science

\section{Wenhui Li}

Beijing Institute of Veterinary Drugs Control

\section{Shaohan Li}

CAAS IAS: Chinese Academy of Agricultural Sciences Institute of Animal Science

\section{Shangjin Cui}

CAAS IAS: Chinese Academy of Agricultural Sciences Institute of Animal Science

\section{Ruiying Liang ( $\square$ liangruiying@caas.cn )}

CAAS IAS: Chinese Academy of Agricultural Sciences Institute of Animal Science

\section{Research Article}

Keywords: feline calicivirus, TaqMan real-time quantitative RT-PCR, detection, application

Posted Date: March 6th, 2021

DOl: https://doi.org/10.21203/rs.3.rs-267291/v1

License: (9) This work is licensed under a Creative Commons Attribution 4.0 International License. Read Full License 


\section{Abstract}

Feline calicivirus (FCV) is an infectious pathogen that causes disease in cats. With the current emergence of FCV-associated virulent systemic disease (FCV VSD) worldwide, the establishment of a rapid, sensitive, and reproducible diagnostic assay for its detection is important to inform prevention and control strategies. In this study, specific primers and TaqMan-FAM probes were designed based on the conserved regions of the FCV genome sequence, and a TaqMan reverse transcriptase quantitative real time PCR assay was established. This assay could specifically detected the FCV genome. The assay had a wide dynamic range, with linear detection in the range of $9.6 \times 10^{9}$ copies $/ \mu \mathrm{L}$ to $9.6 \times 10^{0}$ copies $/ \mu \mathrm{L}$, with a limit of detection of $9.6 \times 10^{0}$ copies $/ \mu \mathrm{L}$, showing high sensitivity and repeatability. In addition, we used this assay to evaluated clinical samples $(n=100)$ taken from cats from across China for the presence/absence of FCV genetic material For samples with low virus content, the positive detection rate of TaqMan reverse transcriptase quantitative real time PCR assay (RT-qPCR) was much higher than that of conventional reverse transcriptase PCR assay (CRT-PCR). And The qRT-PCR assay was used to detect the viral load of cat swabs within 17 days after FCV infection. From days 1-9, the oral and nasal swabs generally had higher viral loads than the anal swabs. While from days 10-17, the levels in the oral and nasal swabs being generally lower than those in the anal swabs. Overall, this FCV TaqMan RT-qPCR assay assay represents a rapid and accurate.

\section{Introduction}

Caliciviruses are a type of RNA virus that can potentially cause serious disease in humans and animals. At present, the family Caliciviridae consists of Saporovirus, Lagovirus, Vesivirus, Nebovirus, and Norovirus. Rabbit hemorrhagic disease virus (RHDV) is a representative virus of the genus Rabbit virus. In 1984, RHDV first broke out in Wuxi and Jiangyin, Jiangsu, China[1]. Subsequently, it was reported on all continents in the world, such as North America and Europe[2, 3]. Among them, the human norovirus and Sapporo virus are the main pathogens that cause acute viral gastroenteritis in humans, collectively known as human calicivirus[4]. Epidemiological surveys show that approximately one-fifth of all acute gastroenteritis cases in the world are caused by noroviruses, with total norovirus infections reaching as high as 267 million person-times, resulting in about 200,000 deaths every year[5]. In 2017-2019, the positive detection rate of norovirus in 904 children with diarrhea under 5 years old in Hohhot, China was as high as $24 \%[6]$. The important public health problems caused by norovirus have attracted more and more attention from the international scientific community. Since noroviruses and most other caliciviruses are difficult to culture in vitro, Feline calicivirus (FCV) of the same family can proliferate in cat kidney cells at high titers, and since animal models are relatively mature, they are often used as models for calicivirus research[7].

The FCV is a representative strain of Caliciviridae and vesicular viruses that can infect all cat species. The virus is distributed worldwide and can spread between species $[8,9]$. FCV infection can cause oral ulcers, chronic stomatitis, pneumonia, and other upper respiratory diseases in cats[10]. In recent years, there have been many reports of FCV-associated virulent systemic disease (FCV VSD) strains in many 
countries. FCV VSD can cause subcutaneous edema, oral ulcers, and different degrees of ulceration of the skin, such as in the auricles and foot pads[11]. It has a very high fatality rate[12]. The high infection rate and variability of FCV provide the necessary conditions for the evolution of FCV, the recombination of various strains, and even the emergence of FCV VSD. At present, vaccination is the main measure to control viral infection, but it does not provide good immune protection for cats; it cannot prevent infection or prevent infected cats from becoming virus carriers[13]. FCV is a non-enveloped RNA virus. FCV is stable in the environment, and the virus can survive for several days to several weeks in dry environment, and longer in cold and wet conditions $[14,15]$. Sick cats, infected cats in the incubation period are the main sources of FCV infection. They can excrete FCV for a long time post infection and pose serious risks to public health [16]. Healthy cats usually get infected through direct contact with sick cats, their secretions, or contaminated equipment[17].

Currently, the methods for FCV detection mainly include virus isolation, electron microscope observation, ELISA detection of antigens or antibodies, PCR, fluorescence-based quantitative PCR, etc[18, 19]. Virus isolation is time-consuming, and coinfection often occurs clinically. Most of the other calicivirus, except FCV, cannot proliferate well in the cells, bringing inevitable problems for the virus isolation. More virions are required for electron microscope observation. Although this method is intuitive but not sensitive, normally virion numbers in the clinical sample usually cannot fulfil the requirements for electron microscope observation. The cost of ELISA detection is relatively high, and there are only a few commercial detection kits on the market with low specificity. Although traditional PCR is widely utilized, its sensitivity is low. Moreover, traditional PCR is not appropriate for detection of some early infections. Fluorescence-based quantitative PCR methods mainly consist of two types, dye-based method and probebased method. Generally, probe-based method is more accurate and more specific than dye-based method in quantitative detection, and is widely used[20]. Therefore, it is of great significance to establish an accurate and rapid FCV detection method for the prevention and control of this disease.

In this study, $41 \mathrm{FCV}$ genome sequences reported in NCBI were compared to determine the conserved regions, and a specific, sensitive, and accurate FCV TaqMan qRT-PCR detection assay was successfully established. Detection of FCV qRT-PCR will lay a foundation for the diagnosis, disease prevention, and molecular epidemiological investigation of FCV, and provide a reference for the molecular biology and epidemiology of noroviruses and other members of Caliciviridae.

\section{Material And Methods}

\subsection{Preparation of virus and tested samples}

Samples containing Feline calicivirus (FCV), feline parvovirus (FPV), feline herpesvirus (FHV-1), canine parvovirus (CPV), and canine coronavirus (CCoV) were collected from pet hospitals in China and identified in our laboratory. A total of 100 clinical samples were obtained from pet hospitals in China between 2019 and 2020. Eight 3-month-old experimental cats weighing $1.5 \mathrm{~kg}$ were purchased from a market in Beijing. They were tested for FCV antigen and all antibody tests were negative. $0.5 \mathrm{ml} \mathrm{FCV} \mathrm{was}$ 
used to instill the eyes on the nose. 1-17 days after challenge, oral, nasal and eye swabs and anal swab were collected. FCV. All samples were kept at $-80^{\circ} \mathrm{C}$ in our laboratory.

\subsection{Design of Primers and TaqMan probes}

Full-length sequences of FCV ( $\mathrm{n}=41$ ) were downloaded from GenBank (https://www.ncbi.nlm.nih.gov/) and aligned using MEGA7.0. The most conservative regions were identified manually for the design of primers and probes. DNAMAN was used to evaluate the physical properties of the primers and TaqMan probes. FCV-BZP-F and FCV-BZP-R primers were expected to amplify a $624 \mathrm{bp}$ fragment. The Primer Express DNAMAN software was then used to prepare the FCV-F and FCV-R qRT-PCR primers and the FCV TaqMan-FAM probe (Table 1), which were predicted to generate a $129 \mathrm{bp}$ fragment. The qRT-PCR probe, labeled at the 5 ' end with FAM and with a dark quencher dye at its $3^{\prime}$ end, was designed to anneal an internal sequence of the amplified region.

\subsection{RNA extraction and reverse transcription}

$1 \mathrm{~g}$ stool samples were diluted with $1 \mathrm{~mL}$ of PBS (Gibco $₫ \mathrm{CA}$ ). After three freeze-thaw cycles, the samples were then spun for $5 \mathrm{~min}$ at $3,000 \mathrm{~g}$ at $4{ }^{\circ} \mathrm{C}$, with supernatants being collected[21]. and stored at $-80^{\circ} \mathrm{C}$ for later use. The viral RNA was extracted using the Qiagen Viral RNA kit (Qiagen, Hilden, Germany), in accordance with to the kit manufacturer's instructions, after which the Reverse Transcription Kit (TIANGEN Beijing, China) was used to prepare cDNA based on provided guidelines. Extracted cDNA was stored at $-20{ }^{\circ} \mathrm{C}$. Every $20 \mu \mathrm{L}$ reverse transcription reaction contained $4 \mu \mathrm{L} 5 \times$ FastKing-RT SuperMix, $2 \mu \mathrm{L}$ Total RNA, and $14 \mu \mathrm{L}$ RNase-Free water. The PCR protocol for the reverse transcription was $15 \mathrm{~min}$ at $42^{\circ} \mathrm{C}$, then 3 min at $95^{\circ} \mathrm{C}$. The synthesized cDNA was stored at $-20^{\circ} \mathrm{C}$ for later use.

\subsection{Preparation of standard plasmids}

The 624 bp target gene fragments were amplified via PCR in a reaction mixture containing $1 \mu \mathrm{L}$ each of the forward and reverse primers (FCV-F and FCV-R, $10 \mu \mathrm{mol} / \mathrm{L}$ ), $2 \mu \mathrm{L} \mathrm{FCV} \mathrm{CDNA} \mathrm{template,} 21 \mu \mathrm{L}$ RNasefree water, and $25 \mu \mathrm{L}$ Prime STAR Max Premix (TaKaRa Biotechnology $₫$ Dalian, China). The thermocycler settings were as follows: $98^{\circ} \mathrm{C}$ for $10 \mathrm{~s}, 55^{\circ} \mathrm{C}$ for $30 \mathrm{~s}, 30$ cycles of $72^{\circ} \mathrm{C}$ for $10 \mathrm{~s}$, and finally $72^{\circ} \mathrm{C}$ for 5 min. The amplified PCR products were incorporated into a pEASY-Blunt cloning vector (TransGen Bitech, Beijing, China), and then transformed into Trans1-T1 competent cells (TransGen Bitech, Beijing, China) according to the manufacturer's guidelines. The bacteria containing positive recombinant plasmids were screened by PCR and sent to a sequencing facility for identification. Plasmids with correct sequences containing the FCV target fragment genes were the standard products. The plasmids were then purified using a commercial column and the plasmid concentration was quantified with a NanoDrop 1000 (ThermoFisher Scientific, USA). The number of plasmid copies in the sample was estimated based on the molecular weight of the plasmid standard and the plasmid concentration. (Calculation formula: copy number $=6.02 * 10^{23}($ copies $/ \mathrm{mol}) \times\left[\right.$ standard concentration $\left.(\mathrm{ng} / \mu \mathrm{L}) \times 10^{-9}\right] /$ standard length $(\mathrm{bp}) \times 660$ (Dalton/bp)). Ten-fold serial dilutions of plasmids were prepared in RNase-free water(Solarbio, Beijing $\mathbb{Z}$ China), and aliquots of each dilution were frozen at $-80^{\circ} \mathrm{C}$. Each aliquot was used only once for qRT-PCR. 
Dilutions of the standard plasmids were tested by qRT-PCR, and a standard curve was generated using Microsoft Excel(USA).

\subsection{Optimization of real-time fluorescence quantitative PCR reaction conditions}

Standard plasmids were amplified via qRT-PCR in an ABI QuantStuio 7 Flex Sequence Detection System (ThermoFisher Scientific, USA) using the Hieff Unicon ${ }^{\circledR}$ qPCR TaqMan Probe Master Mix (Hieff Unicon, China). Each $20 \mu \mathrm{L}$ reaction mix contained $10 \mu \mathrm{L} 2 \times$ Hieff Unicon ${ }^{\circledR}$ TaqMan multiplex qPCR master mix, $0.5 \mu \mathrm{L}$ ROX reference dye as a passive reference, forward and reverse primers (FCV-F and FCV-R, 0.2-1.0 $\mathrm{mol} / \mathrm{L})$, probes $(0.4-0.6 \mathrm{~mol} / \mathrm{L})$, standard plasmids (1-100 ng), and RNase-free water up to $20 \mu \mathrm{L}$. The thermocycler settings were as follows: $95^{\circ} \mathrm{C}$ for $1 \mathrm{~min}$ and $40 \mathrm{~s}, 95^{\circ} \mathrm{C}$ for $10 \mathrm{~s}, 30$ cycles of $50^{\circ} \mathrm{C}$ for $35 \mathrm{~s}$. The data were collected at the annealing step of each cycle and the threshold cycle (Ct) for each sample was calculated by determining the point at which the fluorescence exceeded the threshold limit.

\section{6 qRT-PCR standard curve preparation}

The standard plasmid was serially diluted 10 -fold from $9.6 \times 10^{9}$ copies $/ \mu \mathrm{L}$ to $9.6 \times 10^{0}$ copies $/ \mu \mathrm{L}$. The final standard curve was generated based on the $\mathrm{Ct}$ value and the logarithm of the standard copy number.

\subsection{Specificity test}

The specificity of the assay was evaluated using the above conditions with a range of different viruses (FCV, FPV, FHV-1, CPV, CCoV), together with the negative controls.

\subsection{Sensitivity and reproducibility analyses}

To determine the sensitivity of the assay, standard plasmids were serially diluted 10 -fold with concentrations ranging from $9.6 \times 10^{9}$ to $9.6 \times 10^{0}$ copies $/ \mu \mathrm{L}$. The prepared standard plasmids were amplified with a qRT-PCR system to confirm the detection limit. The sensitivity of this qRT-PCR assay was assessed using a cRT-PCR assay. Intra-assay reliability was evaluated by simultaneously assessing three replicates of each of the three dilution samples. Inter-assay reliability was assessed by repeating three independent experiments. The inter- assay and intra-assay coefficients of variation (CVs) were determined by dividing the standard deviation of each tested sample by its mean prior to multiplying the result by 100 .

\subsection{Clinical sample analyses}

In total, 100 clinical samples were collected from pet hospitals all over China and stored at $-80^{\circ} \mathrm{C}$ in our laboratory. RT-qPCR and RT-PCR assay were performed to compare the detection rates of FCV of the two methods.

\subsection{Detoxification test}


The viral loads of the oral, nasal swabs and the anal swabs collected before and 17 days after the FCV infection were tested, and the law of FCV external detoxification was studied.

\section{Results}

\subsection{Preparation of standard plasmids}

Using the FCV reverse transcription product CDNA as a template, the 624 bp target gene fragments were amplified. Amplified PCR products were incorporated into a pEASY-Blunt cloning vector, and the bacteria containing the positive recombinant plasmid were screened out and sent for sequence identification. After sequencing, BLAST search was performed to match the gene sequences registered in GenBank. Using spectrometry, the concentration of recombinant plasmid standard product was determined to be $480 \mathrm{ng} / \mu \mathrm{L}$ and the copy number was calculated to be $9.6 \times 10^{10}$ copies $/ \mu \mathrm{L}$. This was used as the standard for qRT-PCR and CRT-PCR sensitivity evaluation.

\subsection{Optimization of real-time fluorescence quantitative PCR reaction conditions}

Through optimization of primer concentration and elimination temperature, the optimal qRT-PCR reaction conditions obtained are as follows: $2 \times$ Hieff UNICON qPCR TaqMan Probe Master Mix: $10 \mu \mathrm{L}$; FCV-F (10 $\mu \mathrm{M}) 1.2 \mu \mathrm{L} ; \mathrm{FCV}-\mathrm{F}(10 \mu \mathrm{M}) 1.2 \mu \mathrm{L}$; TaqMan probe Needle $(10 \mu \mathrm{M}) 0.6 \mu \mathrm{L} ; 50 \times$ low Rox $0.4 \mu \mathrm{L}$; template DNA $2 \mu \mathrm{L}$; RNase-free water $4.6 \mu \mathrm{L}$; for a total of $20 \mu \mathrm{L}$ per reaction. The PCR program was: $95^{\circ} \mathrm{C}, 1 \mathrm{~min}$ $40 \mathrm{~s}$; and 45 cycles of $95^{\circ} \mathrm{C}, 10 \mathrm{~s}, 50^{\circ} \mathrm{C}, 35 \mathrm{~s}$.

\section{3 qRT-PCR standard curve preparation}

The standard plasmids were serially diluted 10 -fold from $9.6 \times 10^{9}$ to $9.6 \times 10^{0}$ copies $/ \mu \mathrm{L}$. Refer to the optimized qRT-PCR reaction system and conditions for fluorescent qRT-PCR amplification, and draw a standard curve with reference to the results. The qRT-PCR standard curve is shown in (Figure 1), the linear regression equation is: $y=-3.327 x+43.194, R^{2}=0.9934$, the slope is 3.327 , with the minimum detection limit being 9.6 copies $/ \mu \mathrm{L}$. efficiencies of $90 \%-110 \%$ (efficiency $=\left(10^{(-1 / \text { slope })}-1\right)$ ), were regarded as acceptable. The standard plasmid showed a very good linearity between $9.6 \times 10^{9}$ and $9.6 \times 10^{0} \mathrm{copies} / \mu \mathrm{L}$.

\subsection{Specificity test}

The specificity of the qRT-PCR assay was evaluated using FCV, FPV, FHV-1, CPV, and CCoV, with RNasefree water as a negative control. While strong fluorescent signals were obtained for the FCV sample, all other samples yielded negative results, emphasizing that this assay specifically detects FCV (Figure 2).

\subsection{Assessment of the sensitivity and reproducibility of this real-time PCR assay}

The sensitivity of the qRT-PCR assay was evaluated by testing 10 -fold serial dilutions of the RNA standards $\left(9.6 \times 10^{9}\right.$ to $9.6 \times 10^{0}$ copies $\left./ \mu \mathrm{L}\right)$. Quantitative analysis identified a detection limit of 
approximately 9.6 copies $/ \mu \mathrm{L}$ of viral RNA(Figure 3). The lowest detection limit of the cRT-PCR method was calculated to be approximately $9.6 \times 10^{2}$ to $9.6 \times 10^{3}$ copies $/ \mu \mathrm{L}$ (Figure 4 ).

Standard plasmids with three dilutions of the same batch were used as templates $\left(9.6 \times 10^{7}\right.$ copies $/ \mu \mathrm{L}$, $9.6 \times 10^{4}$ copies $/ \mu \mathrm{L}, 9.6 \times 10^{1}$ copies $\left./ \mu \mathrm{L}\right)$ for the intra-batch reproducibility test, with three replicate wells for each concentration. Three batch-to-batch repeatability tests were performed under the same reaction conditions. The results showed that the coefficients of variation within the groups were $0.8 \%, 0.22 \%$, and $0.66 \%$; the coefficients of variation between groups were $1.9 \%, 1.6 \%$, and $0.72 \%$, all of which were less than $2 \%$ (Table 2). The results showed that the method we developed has good repeatability.

\subsection{Clinical sample testing}

The FCV TaqMan qRT-PCR method established in this study was used to detect 100 clinical samples, with conventional PCR detection performed in parallel. The positive detection rate of the qRT-PCR was $21 \%$, whereas the detection rate of cRT-PCR was only $5 \%$ (Table 3 ). The copy number of five samples was about $1.0 \times 10^{8}$ to $1.2 \times 10^{9}$ copies/ $\mu \mathrm{L}$, and the copy number of 16 samples was about $9.6 \times 10^{0}$ to $3.1 \times 10^{3}$ copies $/ \mu \mathrm{L}$.

\subsection{The progression of the virus infection in artificial infected cats test}

The Taqman qRT-PCR assay established in this study was used to detect the viral load of cat oral, nasal, eyes and anal swabs within 17 days after FCV infection, with three replicates for each sample. Within 117 days after the infection, the virus excretion amount was variable at first and eventually stabilized: the 9 th day had the highest excretion of viruses, with the first 8 days being the unstable stage. The results showed that the oral , nasal, eyes swabs generally had higher viral loads than the anal swabs, and that overall detoxification volume increased with time. From days 10-17, the virus levels in all swabs remained steady, with the levels in the oral and nasal swabs being generally lower than those in the anal swabs ( Figure 5) .

\section{Discussion}

Feline calicivirus is one of the main pathogens that cause respiratory diseases in cats. The typical clinical signs of cats infected with FCV include malaise, mouth and nose ulcers, conjunctivitis, fever, and pneumonia. Some cats showed acute febrile claudication syndrome and other clinical symptoms. The differences in the symptoms was directly related to the virus strain[22]. Since FCV was first isolated from the gastrointestinal tract of sick cats in 1957, it has also been isolated from domestic and wild cats in many countries and regions around the world[8, 23]. A malignant systemic disease (VSD) caused by FCV, with extremely high mortality, was first reported in 1998[24]. Since then, reports of FCV VSD have appeared in many countries, such as Italy, France, and Germany[12, 25, 26]. This disease was associated with a high mortality rate and new clinical characteristics, hence, its discovery could signal the emergence of a highly pathogenic strain in the future. Epidemiological investigations showed that clinically mixed infections of FCV, FHV-1, and FPV often occur[27]. The clinical symptoms of FCV and FHV-1 infections 
are similar, and a differential diagnosis cannot be made based on clinical symptoms alone. As one of the common pathogens in cats, FCV is distributed in all regions of China. Current vaccines on the market cannot provide a comprehensive and effective protection against an epidemic[28]. Therefore, the establishment of an accurate and rapid FCV detection method is important for the prevention and control of the disease. In 2009, Abd-Eldaim M.M. et al. first established the FCV TaqMan fluorescence quantitative detection method, with a minimum detection limit of 70 copies/ $\mu$ L[29]. In 2013, the sensitivity of the method established by Jiang X. et al. was further improved, compared with the method established by Abd-Eldaim M.M.. The minimum detection limit is 22.6 copies/ $\mu \mathrm{L}[30]$. However, we found that its probe region was not conserved through comparing 41 full-length FCV sequences in the NCBI database. Therefore, we compared 41 full-length genome sequences of FCV reported so far, found the conserved region on FCV ORF1, and designed FAM probes to optimize the reaction conditions to detect this sequence. This method does not detect cross-reaction signals of other common viruses of dogs and cats, and the sensitivity of this method has been greatly improved. The minimum detection limit of our method was approximately 2-7 times more sensitive than that of the previous two methods. Our method has good repeatability, with the coefficient of variation within and between groups at less than $2 \%$. Even if different personnel operate, accurate and reliable detection results can be obtained.

After testing the clinical samples, we found that the detection rate of 100 clinical samples was $21 \%$. Among them, five samples with higher virus content had the same results between qRT-PCR and cRT-PCR, but the remaining 16 samples had lower virus content, the detection rate of cRT-PCR was 0 , and the detection rate of Taqman Real-time PCR was $100 \%$. This indicates that the Taqman qRT-PCR is more sensitive and accurate. Epidemiological investigations showed that most of the 16 cats were from catteries and cat farm kittens, which showed fever and mild respiratory symptoms, and were diagnosed with FCV infection by this method. Early diagnosis can enable cat farms to take sufficient time for epidemic prevention, control, and diagnosis, to reduce losses.

At the same time, we used this method to monitor changes in the amount of virus excreted in the 17 days oral, nasal, eyes and anal swabs of four FCV-infected cats. The qRT-PCR Ct value of the oral, nose and eye swabs was $>40.00$ on $1-2$ days, so we determined them to be FCV-negative, that is, the cat did not start detoxification yet. The qRT-PCR Ct value on the 3rd day was 38.61-40.00, which we determined to be FCV-positive. In the results of an FCV pathogenicity test, Wang $\mathrm{H}$. et al. showed that FCV can be detected through nose and eye swabs three days after viral infection, consistent with our conclusions[31]. On the 10th day, the Ct value dropped to 26.96, that is, the detoxification amount reached the maximum; after that, the $\mathrm{Ct}$ value became stable. The results showed that the amount of toxin found in the oral and nasal swabs in FCV-infected cats reached a maximum about 10 days after infection, then they entered a state of continuous detoxification. At 1-17 days, two sets swabs had the similarity changes. At 1-10 days, the oral, nose, and eye swabs for detoxification testing were generally higher than fecal swabs. This might indicate the stage of disease development. Since FCV first replicates in the oral and respiratory tissues, the body might not have completed immune clearance of the virus particles. During this time, the main detoxification method happens in the upper respiratory tract. From the 10-17 days, the virus levels in the oral, nose, eyes and anal swabs remained basically stable, but the virus levels in the oral, nose, and eye 
swabs were generally lower than those in the stool swabs. At this time, the disease may be at a plateau stage. The amount of virus in oral, nose, and eye swabs and anal swabs were not notably different, but the amount of virus in oral, nose, and eye swabs were lesser than that in anal swabs.

The above results indicate that FCV can be transmitted through a variety of ways. The respiratory tract was found to be the main route of FCV transmission within 10 days of infection. After that, it was mainly excreted through fecal waste. The establishment of a specific method to study the external detoxification of FCV is of great significance to reveal the pathogenesis and to help prevent and control the spread of its disease.

Overall, this study established a highly sensitive, specific, and reproducible qRT-PCR detection method for FCV. This method overcomes the limitations of existing detection methods, and can accurately detect and quantify FCV content in samples with low and high viral load. It also provides a new method for pathogen diagnosis, disease prevention, and molecular epidemiological investigation of FCV in cats.

\section{Declarations}

\section{Ethics statement}

All animal experiments were conducted under protocols by Science Research Department (in charge of animal welfare issue) of the Institute of Animal Science, Chinese Academy of Agricultural Sciences (No.IAS2020-95, 3 August 2020). Research was conducted incompliance with the principles stated in the guide for the Care and Useof Laboratory Animals, National Research Council, 1996.

\section{Informed consent}

The author unanimously agreed to submit the manuscript to Archives of Virology.

\section{Conflicts of Interest}

The authors declare that they have no competing interests.

\section{Acknowledgments}

This work was funded by the Agricultural Science and Technology Innovation Program (ASTIP-IAS15); National Key Research and Development Program of China (Nos. 2020-YWF-YTS-10ه2019-YWF-YB-05).

\section{References}

1. Liu S, Xue H, Pu B, Qian N, Xu W, Du N (1984) Anim Husb Vet Med. 6:253-255

2. Duarte MD, Carvalho CL, Barros SC, Henriques AM, Ramos F, Fagulha T, Luis T, Duarte EL, Fevereiro M (2015) A real time Taqman RT-PCR for the detection of rabbit hemorrhagic disease virus 2 (RHDV2). J Virol Methods 219:90-95. 
3. Gregg DA, House C, Meyer R, Berninger M (1991) Viral haemorrhagic disease of rabbits in Mexico: epidemiology and viral characterization. Rev Sci Tech 10:435-51.

4. Matson DO, Szucs G (2003) Calicivirus infections in children. Curr Opin Infect Dis 16:241-6.

5. De Graaf M, Van Beek J, Koopmans MP (2016) Human norovirus transmission and evolution in a changing world. Nat Rev Microbiol 14:421-33.

6. Gong SM, Zhang YG, Yan SH, Lei X (2020) Surveillance of enteric virus pathogens among infants with diarrhea from 2017 to 2019 in Hohhot city of China. Chin. J. Viral Dis 10: 342-345

7. Ettayebi K, Crawford SE, Murakami K, Broughman JR, Karandikar U, Tenge VR, Neill FH, Blutt SE, Zeng XL, Qu L, Kou B, Opekun AR, Burrin D, Graham DY, Ramani S, Atmar RL, Estes MK (2016) Replication of human noroviruses in stem cell-derived human enteroids. Science 353:1387-1393.

8. Tian J, Liu DF, Liu YX, Wu H,X Jiang YM, Zu SP, Liu CG, Sun X, Liu JS, Qu LD (2016) Molecular characterization of a feline calicivirus isolated from tiger and its pathogenesis in cats. Vet Microbiol 192:110-117.

9. Gabriel SS, Tohya Y, Mochizuki M (1996) Isolation of a calicivirus antigenically related to feline caliciviruses from feces of a dog with diarrhea. J Vet Med Sci 58:1041-3.

10. Radford AD, Coyne KP, Dawson S, Porter CJ, Gaskell RM (2007) Feline calicivirus. Vet Res 38:319-35.

11. Ohe K, Takahashi T, Hara D, Hara M (2008) FCV-VBS isolated from cats with typical symptoms caused VSD in experimental cats. Vet Res Commun 32:145-58.

12. Battilani M, Vaccari F, Carelle MS, Morandi F, Benazzi C, Kipar A, Dondi F, Scagliarini A (2013) Virulent feline calicivirus disease in a shelter in Italy: a case description. Res Vet Sci 95:283-90.

13. Ohe K, Sakai S, Takahasi T, Sunaga F, Murakami M, Kiuchi A, Fukuyama M, Furuhata K, Hara M, Ishikawa Y, Taneno A (2007) Genogrouping of vaccine breakdown strains (VBS) of feline calicivirus in Japan. Vet Res Commun 31:497-507.

14. Clay S, Maherchandani S, Malik YS, Goyal SM (2006) Survival on uncommon fomites of feline calicivirus, a surrogate of noroviruses. Am J Infect Control 34:41-3.

15. Duizer E, Bijkerk P, Rockx B, De Groot A, Twisk F, Koopmans M (2004) Inactivation of caliciviruses. Appl Environ Microbiol 70:4538-43.

16. Spiri AM, Meli ML, Riond B, Herbert I, Hosie MJ, Hofmann-Lehmann R囚2019『Environmental Contamination and Hygienic Measures After Feline Calicivirus Field Strain Infections of Cats in a Research Facility. Viruses 11.

17. Gerlich WH, Glebe D (2020) Enigmatic Pres deletions in hepatitis B virus DNA. Virus Genes 56:675676.

18. Guo HM, Miao QH, Zhu J, Yang ZB, Liu GQ (2018) Isolation and molecular characterization of a virulent systemic feline calicivirus isolated in China. Infect Genet Evol 65:425-429.

19. Yuan B, Ai CX, Yuan L, Gao W, Hu JP, Chen J, Ren WZ (2014) Preparation of monoclonal antibody of anti-feline calicivirus and establishment of double-antibody sandwich enzyme-linked immunosorbent assay detecting method. Genet Mol Res 13:7388-97. 
20. Zhou XR, Zhang TS, Song DP, Huang T, Peng Q, Chen YJ, Li AQ, Zhang FF, Wu Q, Ye Y, Tang YX (2017) Comparison and evaluation of conventional RT-PCR, SYBR green I and TaqMan real-time RT-PCR assays for the detection of porcine epidemic diarrhea virus. Mol Cell Probes 33:36-41.

21. Henzel A, Brum MC, Lautert C, Martins M, Lovato LT, Weiblen R (2012) Isolation and identification of feline calicivirus and feline herpesvirus in Southern Brazil. Braz J Microbiol 43:560-8.

22. Dawson S, Bennett D, Carter SD, Bennett M, Meanger J, Turner PC, Carter MJ, Milton I, Gaskell RM (1994) Acute arthritis of cats associated with feline calicivirus infection. Res Vet Sci 56:133-43.

23. Caringella F, Elia G, Decaro N, Martella V, Lanave G, Varello K, Catella C, Diakoudi G, Carelli G, Colaianni ML, Bo S, Buonavoglia C (2019) Feline calicivirus infection in cats with virulent systemic disease, Italy. Res Vet Sci 124:46-51

24. Pedersen NC, Elliott JB, Glasgow A, Poland A, Keel K (2000) An isolated epizootic of hemorrhagic-like fever in cats caused by a novel and highly virulent strain of feline calicivirus. Vet Microbiol 73:281300.

25. Reynolds BS, Poulet $H$, Pingret JL, Jas D, Brunet S, Lemeter C, Etievant M, Boucraut-Baralon C (2009) A nosocomial outbreak of feline calicivirus associated virulent systemic disease in France. $J$ Feline Med Surg 11:633-44.

26. Schulz BS, Hartmann K, Unterer S, Eichhorn W, Majzoub M, Homeier-Bachmann T, Truyen U, Ellenberger C, Huebner J (2011) Two outbreaks of virulent systemic feline calicivirus infection in cats in Germany. Berl Munch Tierarztl Wochenschr 124:186-93.

27. Liu C, Liu Y, Qian P, Cao Y, Wang J, Sun C, Huang B, Cui N, Huo N, Wu H, Wang L, Xi X, Tian K. 2020. Molecular and serological investigation of cat viral infectious diseases in China from 2016 to 2019. Transbound Emerg Dis 67:2329-2335.

28. Radford AD, Bennett M, McArdle F, Dawson S, Turner PC, Glenn MA, Gaskell RM (1997) The use of sequence analysis of a feline calicivirus (FCV) hypervariable region in the epidemiological investigation of FCV related disease and vaccine failures. Vaccine 15:1451-8.

29. Abd-Eldaim MM, Wilkes RP, Thomas KV, Kennedy MA (2009) Development and validation of a TaqMan real-time reverse transcription-PCR for rapid detection of feline calicivirus. Arch Virol 154:555-60.

30. Jiang X, Gao YW, HU GX, Yang ST, Zhao YL, Liu QY, Xu CZ, Liang XJ, Xia XZ (2013) Development and Preliminary Application of Real-Time PCR Assay. J Jilin Univ 51:973-977

31. Wang H, Bai AB, Liu JF, Wan Q, Ling HT, Qin SY, Tan SM, Wu JM (2020) Isolation,identification and pathogenicity of three strains of feline calicivirus [J]. Chin Vet Sci 50:717-724

\section{Tables}

Table 1. Primer and probe sequence 


\begin{tabular}{|c|c|c|c|}
\hline $\begin{array}{l}\text { Primer } \\
\text { Probe }\end{array}$ & names & Primer sequences $\left(5^{\prime} \rightarrow 3^{\prime}\right)$ & Size/bp \\
\hline Forward & FCV-F & 5'-GGRAARATTGTCAATGAHARBGT-3' & \multirow[t]{2}{*}{129} \\
\hline Reverse & FCV-R & 5'-ACATCATATGCGGCTCTGA-3' & \\
\hline Probe & FCV-P & 5'-FAM-CCGCCAATCAACATGTGGTAA-BHQ-3' & \\
\hline Forward & FCV-BZP-F & AAATATTGACTCCTTGGCCCAAAC & \multirow[t]{2}{*}{624} \\
\hline Reverse & FCV-BZP-R & AATAAACTGCGTCACCACATGGTC & \\
\hline
\end{tabular}

Table 2. Results of the repeatability test of the qRT- PCR assay $(n=3)$.

\begin{tabular}{|lllll|}
\hline Concentration of standard & \multicolumn{2}{l}{ Intra-assay variability } & \multicolumn{2}{l|}{ Inter-assay variability } \\
\cline { 2 - 5 } plasmids (copies $/ \mu \mathrm{L})$ & $\pm S D$ & $\mathrm{CV}(\%)$ & $\pm S D$ & $\mathrm{CV}(\%)$ \\
\hline $9.6 \times 10^{7}$ & $14.93 \pm 0.12$ & 0.80 & $15.33 \pm 0.30$ & 1.90 \\
\hline $9.6 \times 10^{4}$ & $26.04 \pm 0.06$ & 0.22 & $26.51 \pm 0.42$ & 1.60 \\
\hline $9.6 \times 10^{1}$ & $35.22 \pm 0.23$ & 0.66 & $35.31 \pm 0.25$ & 0.72 \\
\hline
\end{tabular}

Table 3. qRT-PCR and cRT-PCR clinical sample detection.

\begin{tabular}{|c|c|c|c|c|}
\hline Detection & Positiive samples & \multicolumn{2}{|c|}{ Total samples } & Positiive rate \\
\hline cRT-PCR & 5 & 100 & $5 \%$ & \\
\hline qRT-PCR & 21 & 100 & $21 \%$ & \\
\hline
\end{tabular}

\section{Figures}




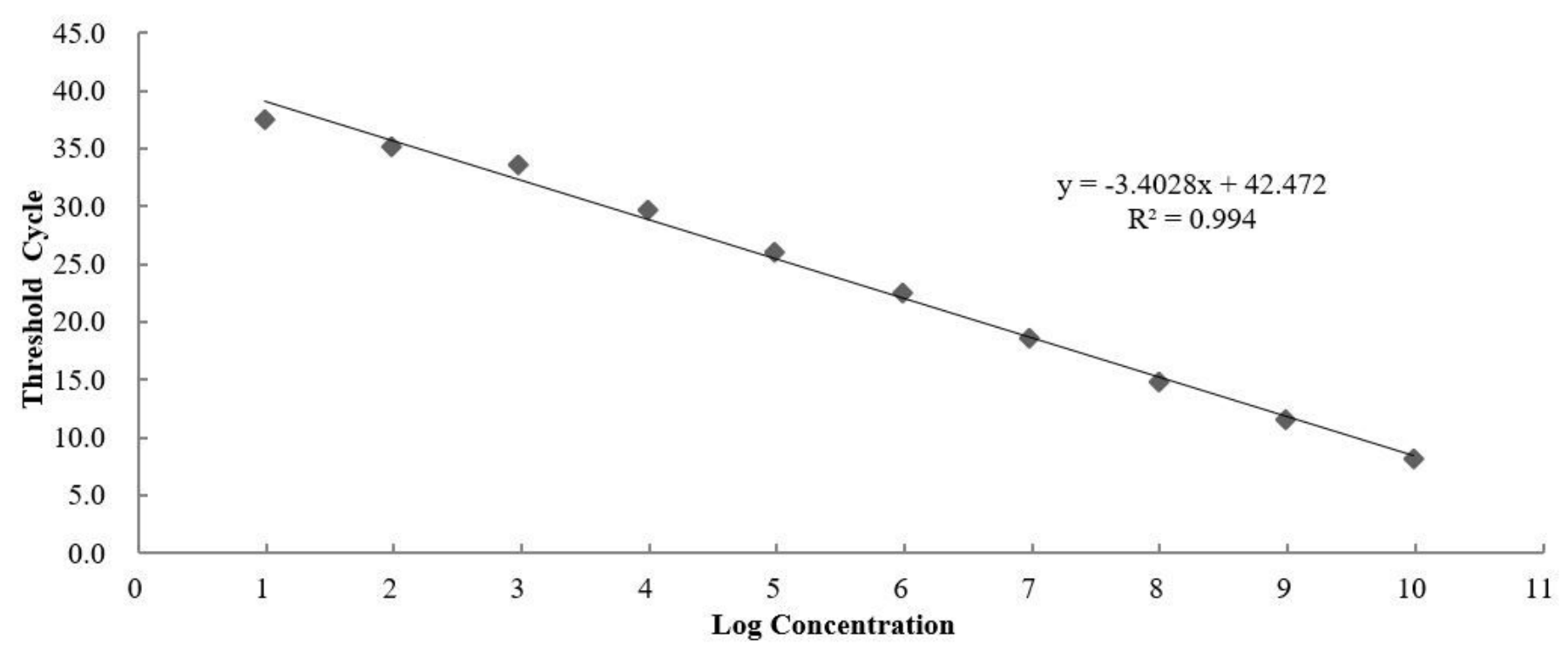

\section{Figure 1}

Standard curve for the qRT-PCR assay of FCV. The X-axis represents the plasmid copy numbers and the Yaxis represents the cycle threshold (Ct). The optimal standard formula is $y=-3.45028 x+42.472$, with a correlation coefficient of 0.994 .

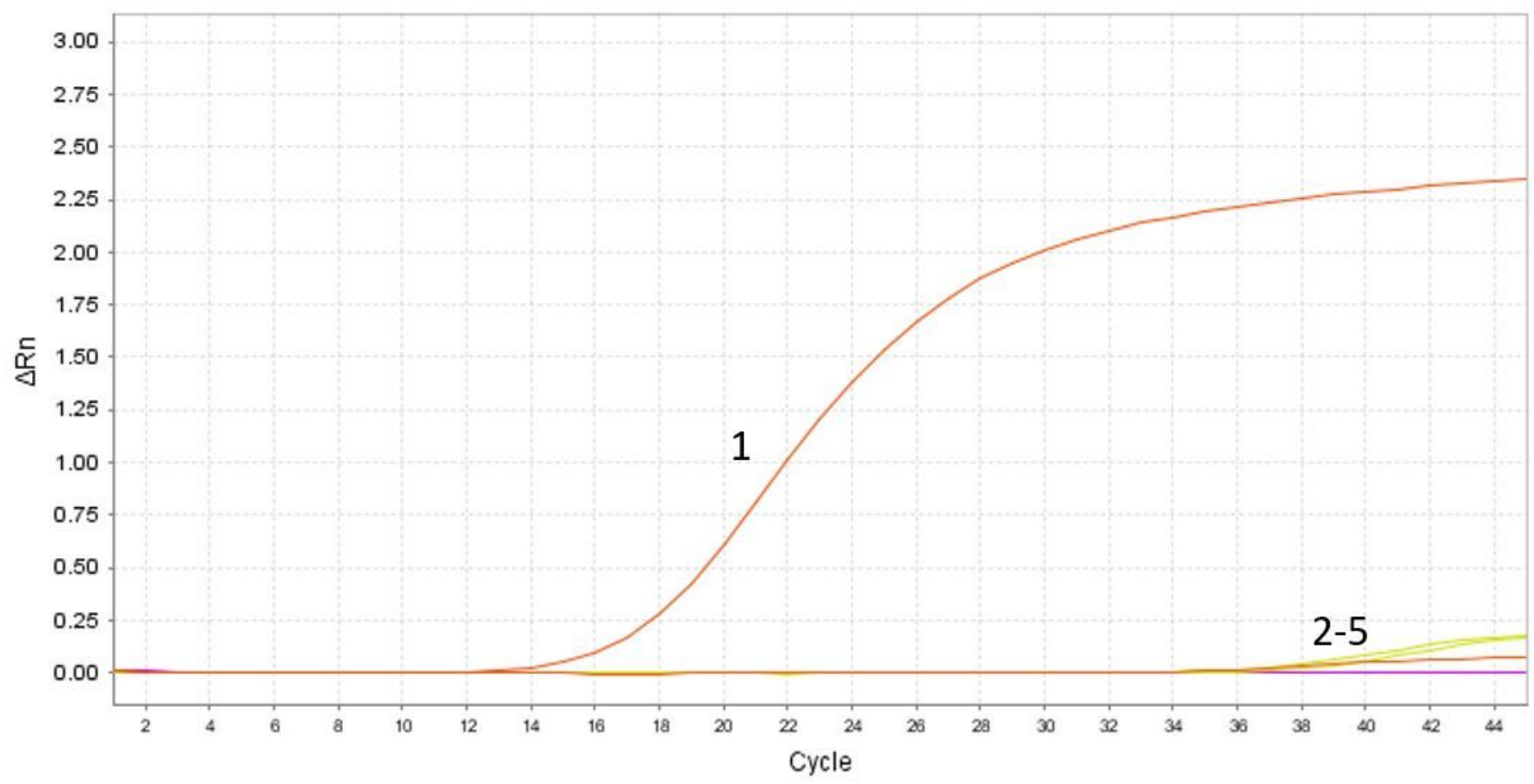

Figure 2 
The specificity of the qRT-PCR assay. The X-axis represents the cycle number and the Y-axis represents the fluorescence data. 1. FCV (positive sample), 2-5. FPV, FHV-1, CPV, CCoV, and RNase-free water as negative control.

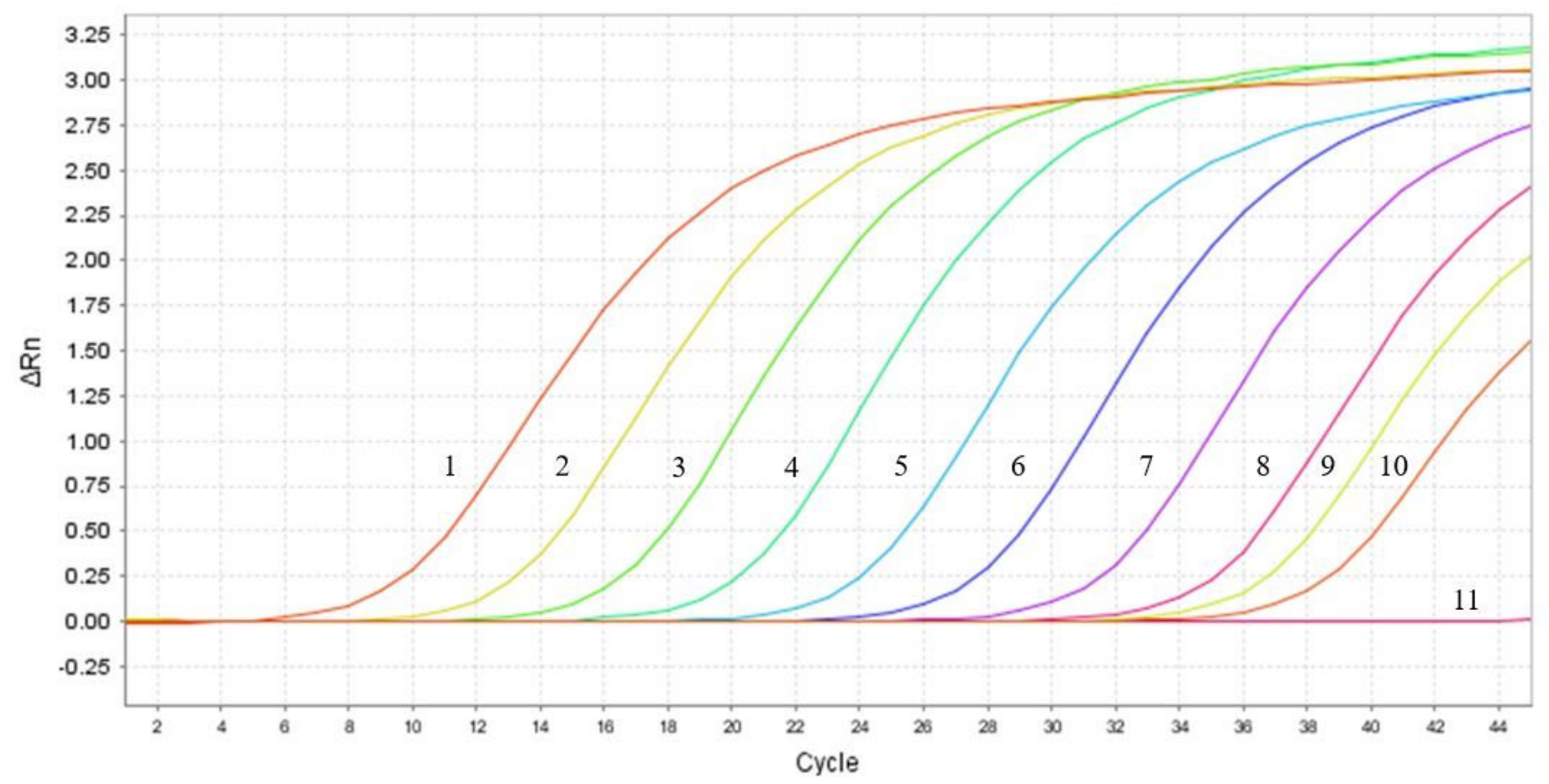

\section{Figure 3}

A 10 - fold serial dilutions ranging from $9.6 \times 109$ to $9.6 \times 100$ copies/ $\mu \mathrm{L}$ of standard plasmid were tested in the qRT-PCR. The X-axis represents the cycle number and the $Y$-axis represents the fluorescence data. Curves1-10: $9.6 \times 109$ to $9.6 \times 100$ copies/ $\mu \mathrm{L}$ of standard plasmid, Curve 11: RNase-free water as negative control.

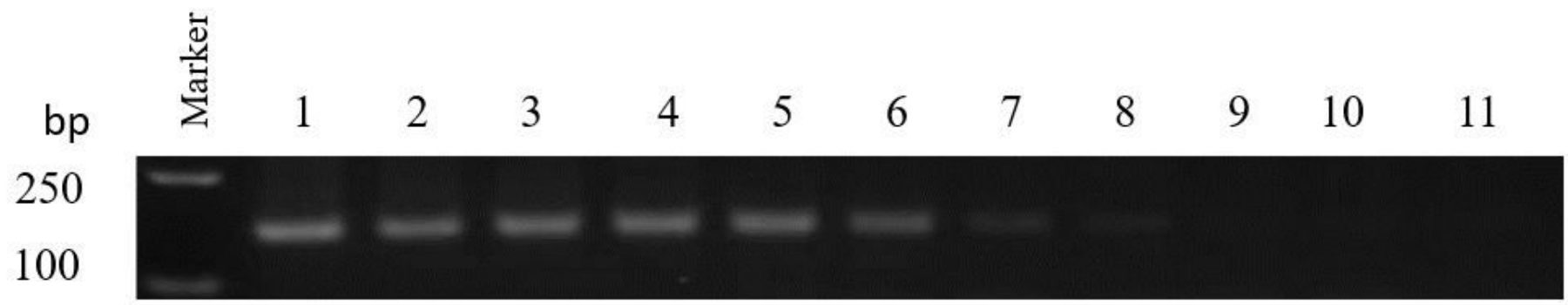

\section{Figure 4}

A 10 -fold serial dilutions ranging from $9.6 \times 109$ to $9.6 \times 100$ copies $/ \mu \mathrm{L}$ of standard plasmid were tested in CRT-PCR. Lanes1-10: $9.6 \times 109$ to $9.6 \times 100$ copies/ $\mu \mathrm{L}$ of standard plasmid, Lane 11: RNase-free water as 
negative control.

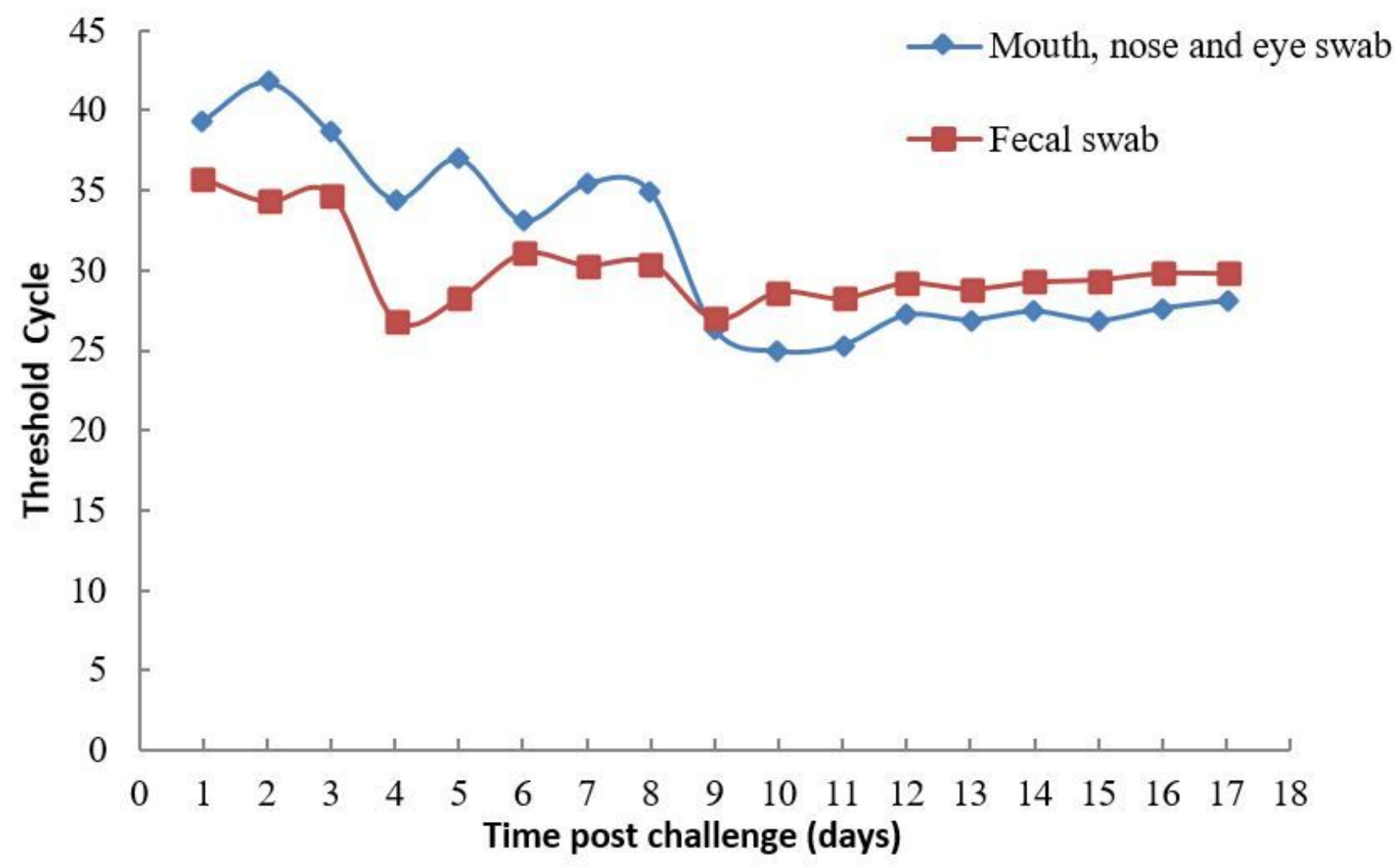

Figure 5

Detection of the amount of viral discharge at different times after FCV infection. 